\title{
PENINGKATAN KEMAMPUAN PROMOSI MELALUI PELATIHAN DESAIN PROMOSI BERBASIS TEKNOLOGI QR-CODE
}

\author{
Dewi Muliyatia), Siswoyo ${ }^{\text {b) }}$ \\ Program Studi Pendidikan Fisika, Fakultas Matematika dan Ilmu Pengetahuan Alam, \\ Universitas Negeri Jakarta, Jl Rawamangun Muka No.1, Jakarta 13220, Indonesia
}

Email: ${ }^{\text {a)}}$ Corresponding Author: dmuliyati@unj.ac.id, ${ }^{\text {b) }}$ siswoyo@unj.ac.id

\begin{abstract}
Information and communication technology (ICT) contributes significantly to the optimization of the promotional design. QR-Code is one of the technologies that can improve promotional media to be more informative and interactive, especially visual media. The various information embedded in the QR-Code can provide varied impressions to the user. On many occasions, QR-Code can even direct to transactions. This advantage is packaged in a simple appearance because it is a one-dimensional to two-dimensional development of barcodes. These characteristics make QR-Code as a designing promotional media technology that every business actor must mastering. This paper describes the training conducted to improve promotional design skills that are integrated with QR-Code technology. The training is carried out in collaboration with Rumah Siap Kerja, through the video conference platform. The training results show an increase in knowledge and skills in integrating QR-Code technology into promotional media.
\end{abstract}

Keywords: promotion design; visual media; QR-Code technology

\begin{abstract}
Abstrak
Teknologi informasi dan komunikasi (TIK) berkontribusi besar dalam optimasi desain promosi. QR-Code menjadi salah satu pilihan teknologi yang mampu meningkatkan media promosi menjadi lebih informatif dan interaktif, terutama media promosi jenis visual. Berbagai informasi yang ditanamkan dalam QR-Code dapat memberikan impresi yang bervariatif kepada pengguna. Dalam banyak kesempatan, QR-Code bahkan dapat mengarahkan terjadinya transaksi. Keunggulan ini dikemas dalam tampilan yang sederhana karena pada dasarnya merupakan pengembangan barcode satu dimensi ke dua dimensi. Karakteristik ini menjadikan QR-Code sebagai teknologi yang wajib dikuasai oleh setiap pelaku usaha dalam mendesain media promosi. Makalah ini memaparkan pelatihan yang dilakukan untuk meningkatkan kemampuan desain promosi yang terintegrasi dengan teknologi QR-Code. Pelatihan dilaksanakan atas kerjasama dengan Rumah Siap Kerja secara daring melalui platform video conferences. Hasil pelatihan menunjukkan peningkatan pengetahuan dan keterampilan dalam mengintegrasikan teknologi QR-Code ke dalam media promosi.
\end{abstract}

Kata Kunci: desain promosi; media visual; teknologi QR-Code

\section{PENDAHULUAN}

Integrasi teknologi informasi dan komunikasi (TIK) dalam bidang pemasaran, terbukti dapat meningkatkan penjualan (Mas'ud, 2017) yang berujung pada peningkatan pendapatan produsen (Basry, 2018). Pemanfaatan TIK dalam pemasaran lebih dikenal dengan istilah digital marketing (Febriyantoro, 2018). Berbagai upaya dilakukan untuk memasukkan unsur TIK di setiap strategi marketing, termasuk di dalamnya desain promosi (Rewah, 2018). Beberapa jenis desain promosi yang jelas 
mengintegrasikan TIK di antaranya melalui pengembangan website sebagai sistem informasi pemasaran (Hernandhi, 2018), media visual dalam bentuk katalog produk (Hidayat, 2016), optimasi mesin pencari (Hayaty, 2018), sampai dengan penggunaan media yang kompleks seperti virtual reality (Triani, 2018).

Media visual menjadi media paling dasar untuk promosi. Karena media jenis ini melekatkan identitas dari suatu entiti bisnis atau usaha (Haiqal, 2017; Yusantiar, 2018). Karakter media visual ini menghasilkan sebuah urgensitas untuk memadukan pesan yang dibawa dengan keunggulan media promosi berbasis TIK. Setiap media tentu memiliki sasaran pasar atau target yang berbeda. Media visual selalu memiliki perannya sendiri termasuk di era penjualan serba digital. Hal ini karena setiap akses informasi tak lepas dari unsur visual. Saat ini, semua media yang sudah berbasis TIK dapat dengan mudah diakses karena ketersediaan internet di Indonesia semakin meningkat.

Akses internet di Indonesia saat ini sudah semakin luas tiap tahunnya. Berdasarkan survey yang dilakukan oleh Asosiasi Penyelenggara Jasa Internet Indonesia (APJII, 2016) pada tahun 2016 lebih dari 124,4 juta masyarakat Indonesia menggunakan internet dalam kesehariannya. Dalam survey tersebut ada beberapa alasan utama pengguna internet di Indosesia di antaranya mereka mengakses internet untuk update informasi sebanyak 25,3\% (31 juta jiwa), terkait pekerjaan 20,8\% ( 27,6 juta jiwa), mengisi waktu luang (17,9 juta jiwa), sosialisasai $10,3 \%$ (13,6 juta jiwa), terkait pendidikan 9,2\% (12,2 juta jiwa), hiburan $8,8 \%$ (11,7 juta jiwa) dan terakhir alasan utama pengguna internet di Indonesia adalah untuk bisnis, berdagang dan mencari barang-barang kebutuhan sebanyak 8,5\% (10,4 juta jiwa). Jika dilihat dari hasil survey tersebut kegiatan bisnis, berdagang, dan mencari barang menjadi alasan terakhir mengakses internet yaitu $8,5 \%$. Meskipun demikian, angka 8,5\% yaitu sebanyak 10,4 juta jiwa bukan angka yang kecil, seiring berkembangnya teknologi dan informasi angka pengguna internet akan semakin bertambah dan alasan pengguna internet untuk kegiatan bisnis, berdagang serta mencari barang juga akan semakin bertambah.

Kegiatan bisnis, berdagang, dan mencari barang yang dilakukan secara online oleh pengguna internet di Indonesia bisa melalui beberapa perusahaan e-commerce seperti tokopedia, bukalapak, shopee, lazada, dan lain-lain. Menurut data yang diambil dari situs tokopedia.com, pada tahun 2019 terhitung lebih dari 7 juta masyarakat Indonesia telah memulai dan mengembangkan bisnis lewat Tokopedia untuk memasarkan lebih dari 200 juta produk terdaftar dengan harga transparan.

Di sisi lain, sistem manajemen toko yang terpercaya menjadi kunci keberhasilan penjualan. Seperti kita ketahui, di Indonesia, marketplace menjadi tempat transaksi terpercaya. Banyak produsen beralih. Karena selain menyediakan informasi, marketplace ini mampu menyediakan profile toko secara 
lebih rapi karena merupakan sistem manajemen. Namun, dari lebih 7 juta toko yang dikembangkan di tokopedia, masih ada toko yang memiliki performa buruk, artinya memiliki rating di bawah 3. Performa toko yang buruk atau tidak memiliki performa dapat menjadi alasan toko tersebut dimoderasi atau ditutup sementara. Dalam laman penjual, tokopedia menyarankan beberapa hal yang harus dilakukan penjual untuk meningkatkan performa yaitu dengan melakukan lebih banyak transaksi penjualan. Menurut penelitian yang dilakukan oleh (Khair, 2016) keputusan masyarakat untuk membeli suatu produk dipengaruhi oleh atribut toko meliputi performa dan bentuk promosi. Toko dengan performa buruk harus membuat desain promosi agar menarik pembeli dan melakukan lebih banyak transaksi. Yang menjadi gap adalah bagaimana menghubungkan media promosi visual yang langsung mengarahkan calon pembeli atau pelanggan tepat ke laman yang kita atur di marketplace. Hal ini bertujuan promosi visual dapat terhubung dengan sistem manajemen toko baik di marketplace maupun di website toko.

Strategi untuk menjawab gap antara media promosi dengan media transaksi dapat diselesaikan dengan teknologi QRCode. Kode QR (Quick Response) merupakan bentuk evaluasi dari barcode yang biasanya kita lihat pada sebuah produk. Kode QR berbentuk persegi berwarna hitam seperti barcode tetapi dengan tampilan yang lebih ringkas. Kode QR memuat berbagai informasi di dalamnya seperti Alamat URL, teks hingga nomor telepon, Kode QR biasanya diletakan diberbagai produk untuk menunjukan informasi tambahan dari produk tersebut. Untuk membaca kode QR, dibutuhkan smartphone berkamera dan sebuah aplikasi pembaca QR (Daulay, 2015). Kode QR bisa dipakai sebagai media informasi untuk poster untuk mempromosikan toko atau produk yang dijual.

Penggunaan QR Code yang secara spesifik untuk promosi sudah dilakukan sejak lama karena diyakini sebagai alat pemasaran yang efektif (Asare, 2015). QR-Code sebagai media promosi memiliki keunggulan karena dapat menyimpan berbagai jenis informasi dan mengarahkan user ke informasi berikutnya sebagai bentuk interaksi. Hal ini ditunjukkan dalam makalah-makalah dari penelitian sebelumnya, pemanfaatan QR-Code dalam jejaring sosial (Čović, 2016), media pembelian dan transaksi (Hossain, 2018), serta QR-Code estetik untuk semua aplikasi komersial (Lin, 2017). Dari berbagai contoh penerapan teknologi sederhana dengan pengaruh yang luar biasa ini pemanfaatan $Q R$ Code perlu menjadi perhatian utama bagi para pelaku jual-beli, terutama UMKM yang baru bertumbuh. Menurut penelitian sebelumnya (Irawan, 2018) desain promosi menggunakan kode ini dan dengan bantuan internet maka akan terbentuk suatu sistem promosi dengan biaya murah tetapi dapat mencakup area yang sangat luas.

Makalah ini memaparkan pelatihan pembuatan sampai dengan penggunaan teknologi QR-Code dalam media promosi. Tingkat pengetahuan peserta 
sebelum dan sesudah pelatihan juga direkam. Pelatihan daring ini meliputi topik-topik: dasar QR-Code, jenis-jenis informasi dalam QR-Code, desain promosi produk, pembuatan QR-Code, serta integrasi QR-Code dalam media promosi. Setelah paparan materi, peserta diberikan kesempatan untuk memperbaiki desain yang dibuat bersama secara synchronize, untuk kemudian dinilai dan dievaluasi.

\section{METODE PELAKSANAAN}

Pelatihan ini dilakukan secara daring dengan kombinasi synchronous melalui video conference dan synchronous melalui portal pengumpulan tugas sebagai output pelatihan. Pelatihan dilaksanakan pada 15 Juni 2020 melalui video conference kemudian dilanjutkan dengan portal pengumpulan tugas. Setiap peserta harus membuat desain promosi untuk usaha yang sedang atau akan dijalankan. Desain promosi harus sesuai dengan

a)

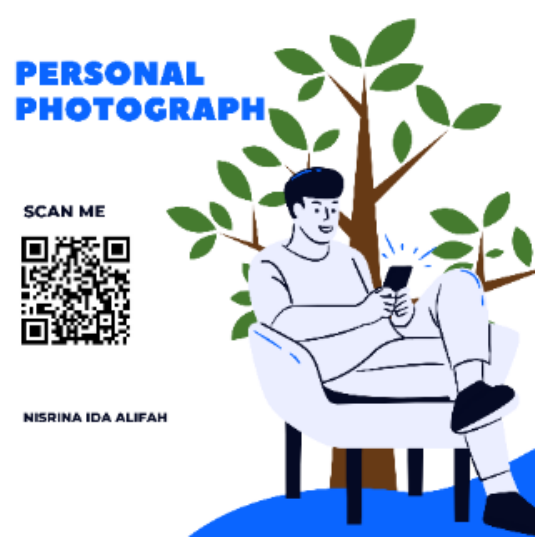

spesifikasi pada media sosial tertentu dan terdapat QR-Code yang berisi informasi. Informasi yang ditanamkan dapat berupa direct link ke profil toko di website atau marketplace.

\section{HASIL DAN PEMBAHASAN}

Kegiatan pelatihan ini menghasilkan output karya berupa desain promosi oleh setiap peserta. Di akhir kegiatan juga dilaksanakan evaluasi kegiatan. Evaluasi ini meliputi wawasan peserta mengenai media promosi dan teknologi QR-Code, urgensitas materi, dan kejelasan narasumber.

\section{Karya Peserta Pelatihan}

Berikut ditampilkan beberapa karya peserta pelatihan. Gambar 1 menunjukkan media promosi dengan QR-Code dan konten informasi berupa link informasi ke media sosial. Gambar 1 menunjukkan bahwa peserta sudah mampu menanamkan informasi berupa URL media sosial toko atau usaha atau event.

Gambar 1. Contoh promosi dengan QR-Code berupa direct link ke media sosial: (a) instragram, (b) YouTube. 

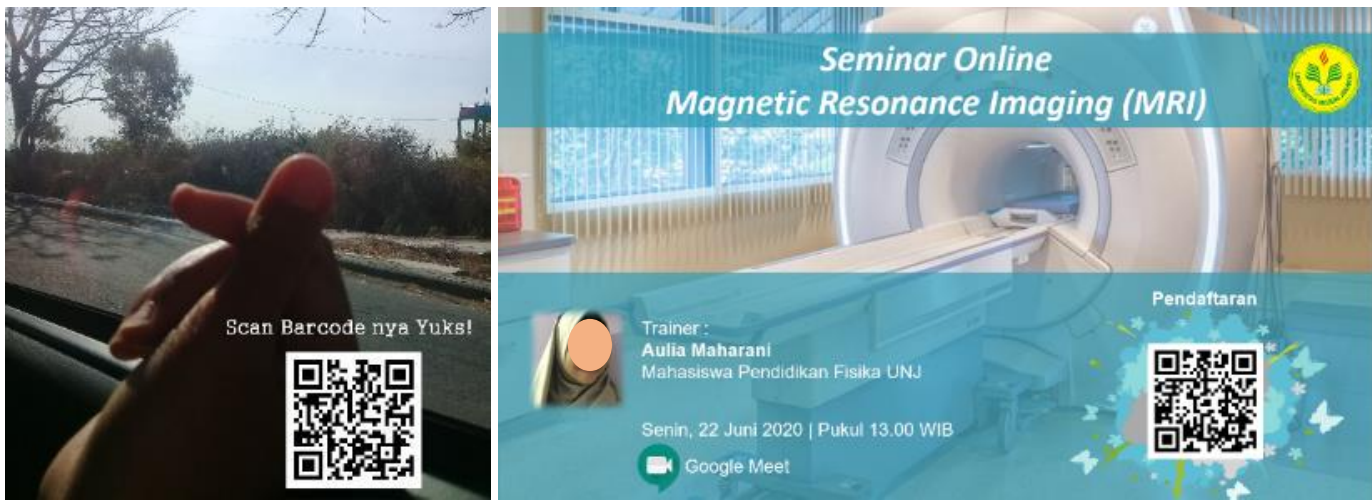

Gambar 2. Contoh promosi dengan QR-Code berupa direct link ke web profile.

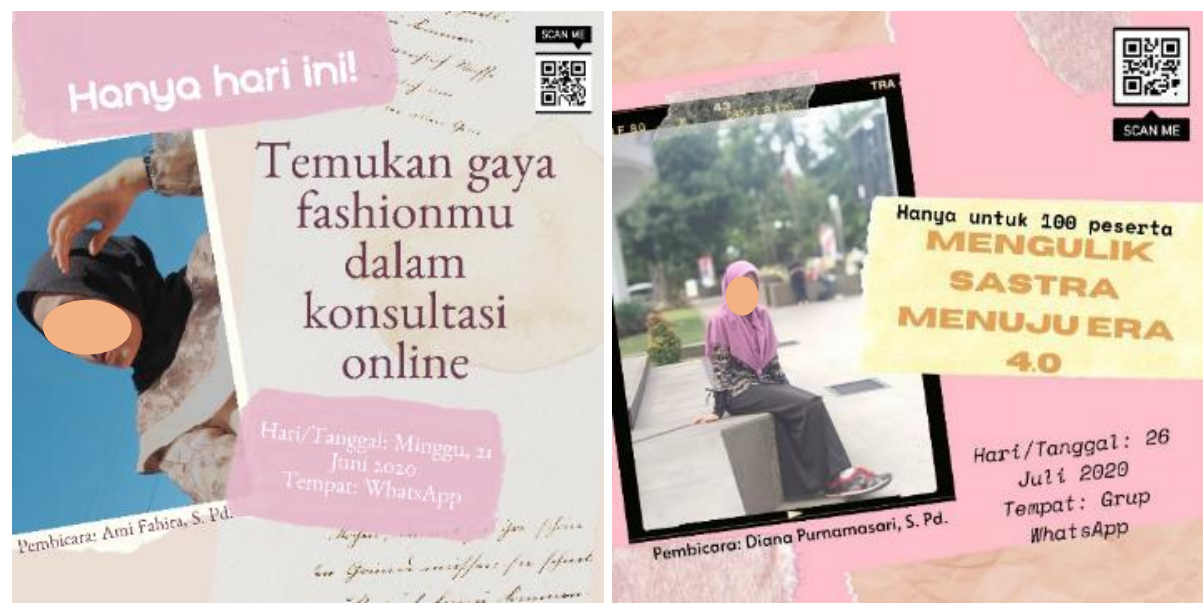

Gambar 3. Contoh promosi dengan QR-Code berupa nomor telepon.
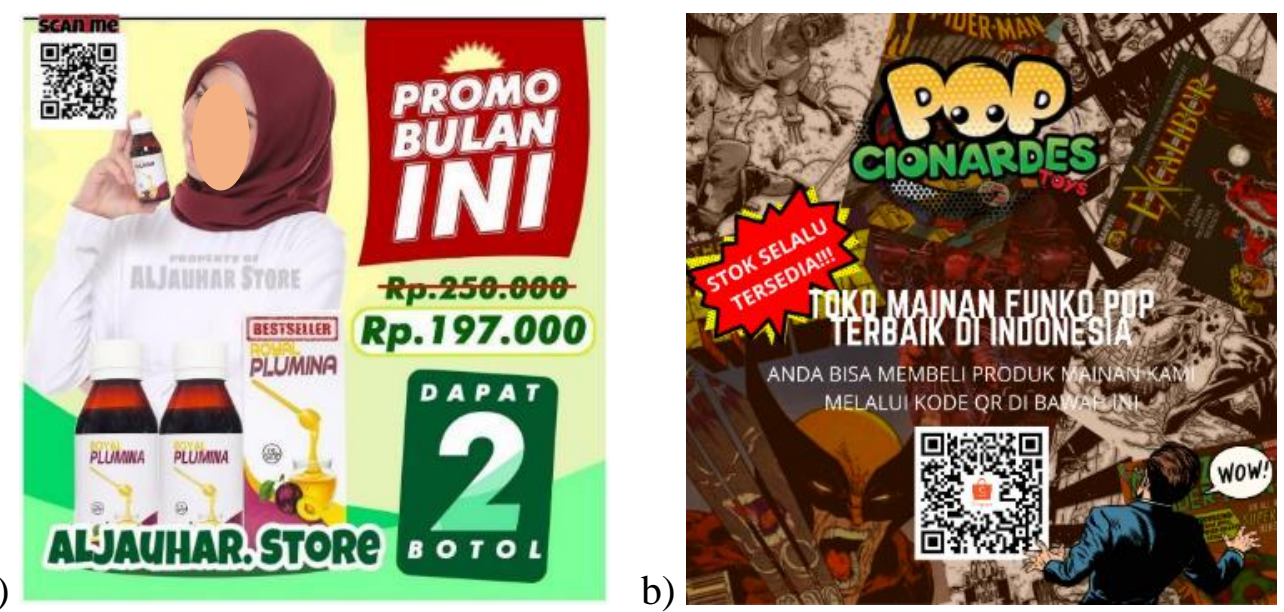

Gambar 4. Contoh promosi dengan QR-Code berupa direct link ke marketplace: a) tokopedia, b) shopee.

Prinsip yang sama dengan Gambar 1, Gambar 2 adalah contoh QR-Code dengan konten berisi link URL ke laman website toko atau web profile. Selanjutnya Gambar 3 menunjukkan contoh media promosi dengan QR-Code 
yangmenyimpan konten berupa nomor telepon toko atau penyelenggara sebuah event. Selanjutnya Gambar 4 menunjukkan contoh QR-Code dengan direct ke laman transaksi ke marketplace, dalam hal ini laman tokopedia dan shopee. Dari Gambar 4, kita dapat menilai bahwa peserta pelatihan mampu menggabungkan 3 hal sekaligus, yaitu desain promosi visual, interaksi QR-Code, dan transaksi ke marketplace.

\section{Evaluasi Kegiatan}

Evaluasi terdiri dari wawasan peserta mengenai media promosi dan teknologi QR-Code, urgensitas materi, dan kejelasan narasumber.

Gambar 5 dan Gambar 6 menunjukkan grafik atas kuesioner pengetahuan dan wawasan tentang QRCode peserta sebelum dan sesudah mengikuti kegiatan pelatihan. Dari grafik ini kita dapat melihat terjadi pergeseran ke arah kanan. Untuk rentang skala 0 - 2, tereduksi menjadi $0 \%$ setelah pelatihan. Hal ini menunjukkan kegiatan pelatihan memberikan dampak yang positif bagi peningkatan pengetahuan dan wawasan tentang QRCode.

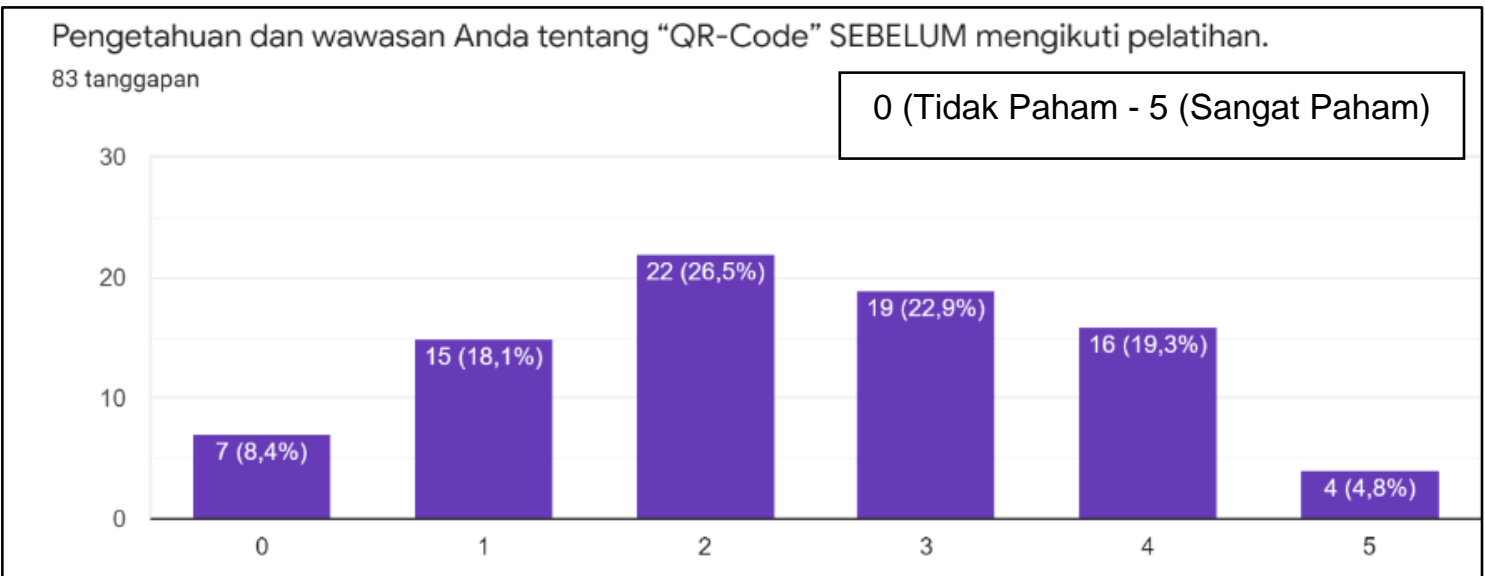

Gambar 5. Grafik pengetahuan dan wawasan peserta tentang QR-Code sebelum mengikuti pelatihan.

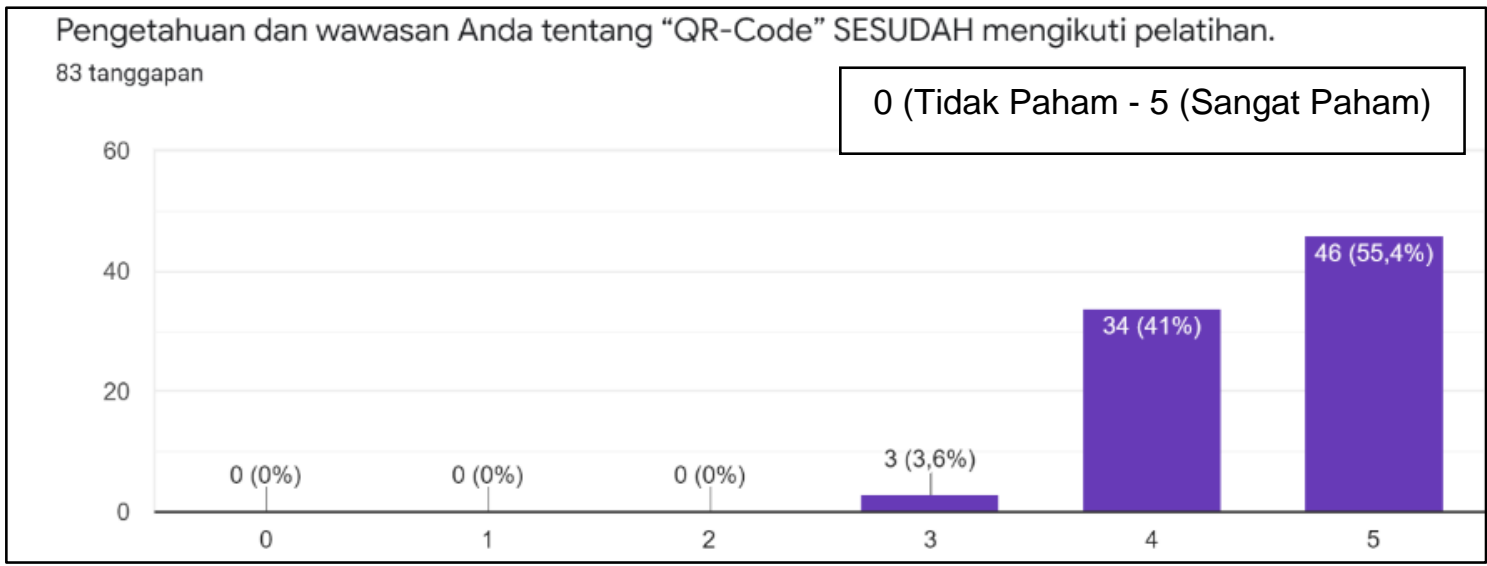

Gambar 6. Grafik pengetahuan dan wawasan peserta tentang QR-Code sesudah mengikuti pelatihan. 


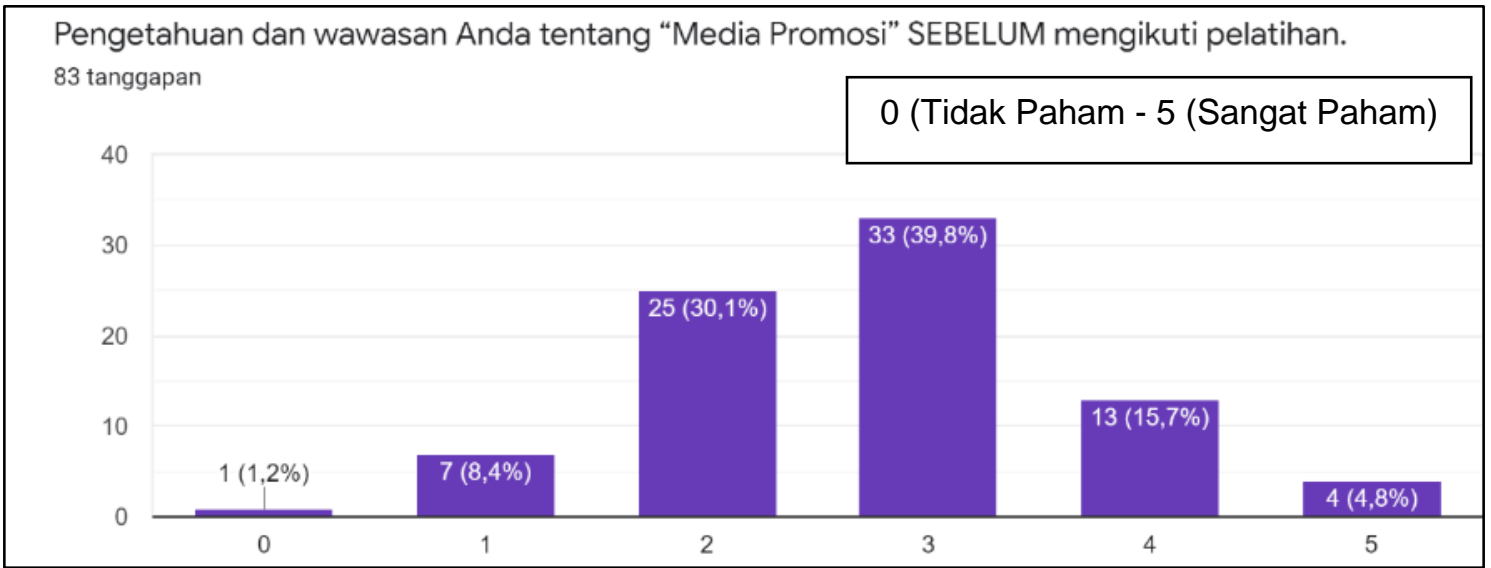

Gambar 7. Grafik pengetahuan dan wawasan peserta tentang media promosi sebelum mengikuti pelatihan.

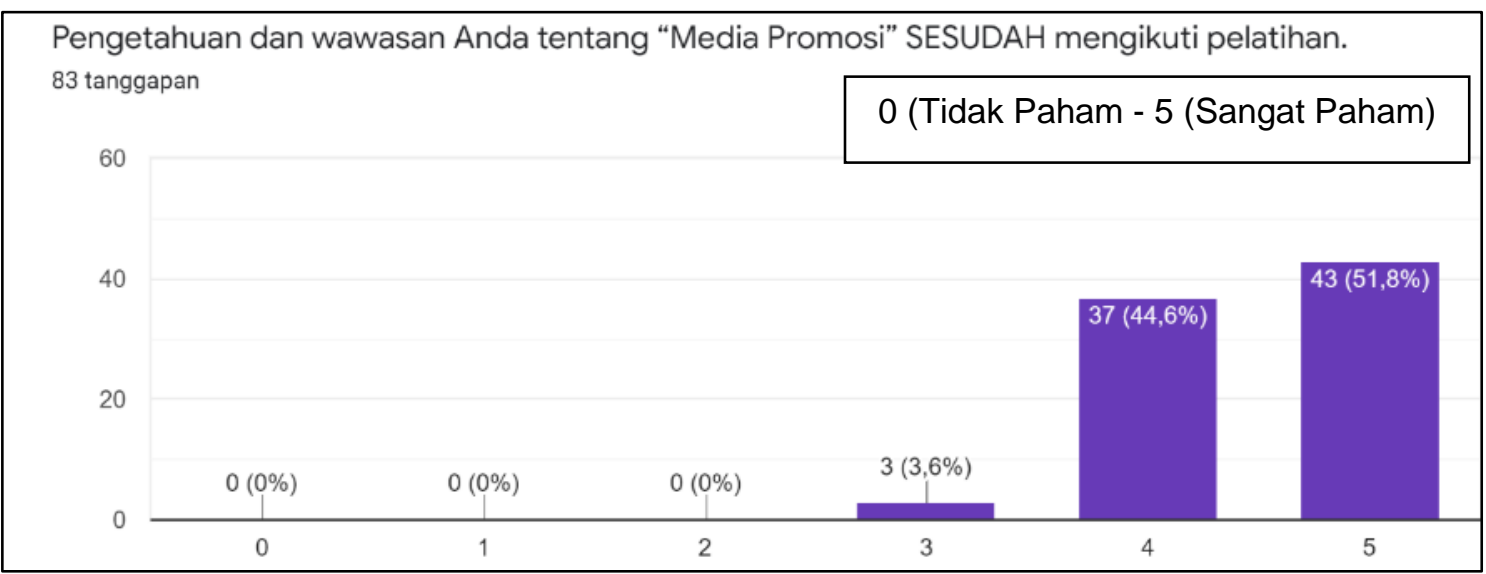

Gambar 8. Grafik pengetahuan dan wawasan peserta tentang media promosi sesudah mengikuti pelatihan.

Seberapa penting materi yang disampaikan.

83 tanggapan

\section{0 (Tidak Penting - 5 (Sangat Penting)}

60

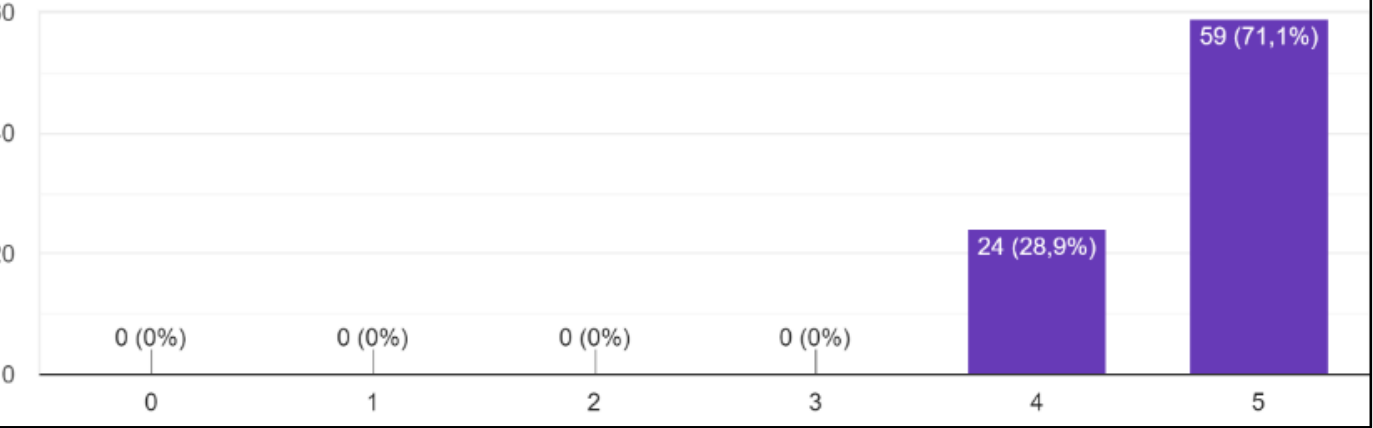

Gambar 9. Grafik tanggapan peserta mengenai urgensitas materi pelatihan.

Sarwahita : Jurnal Pengabdian Kepada Masyarakat Vol. 17 No. 1 Tahun $2020 \mid 89$ 


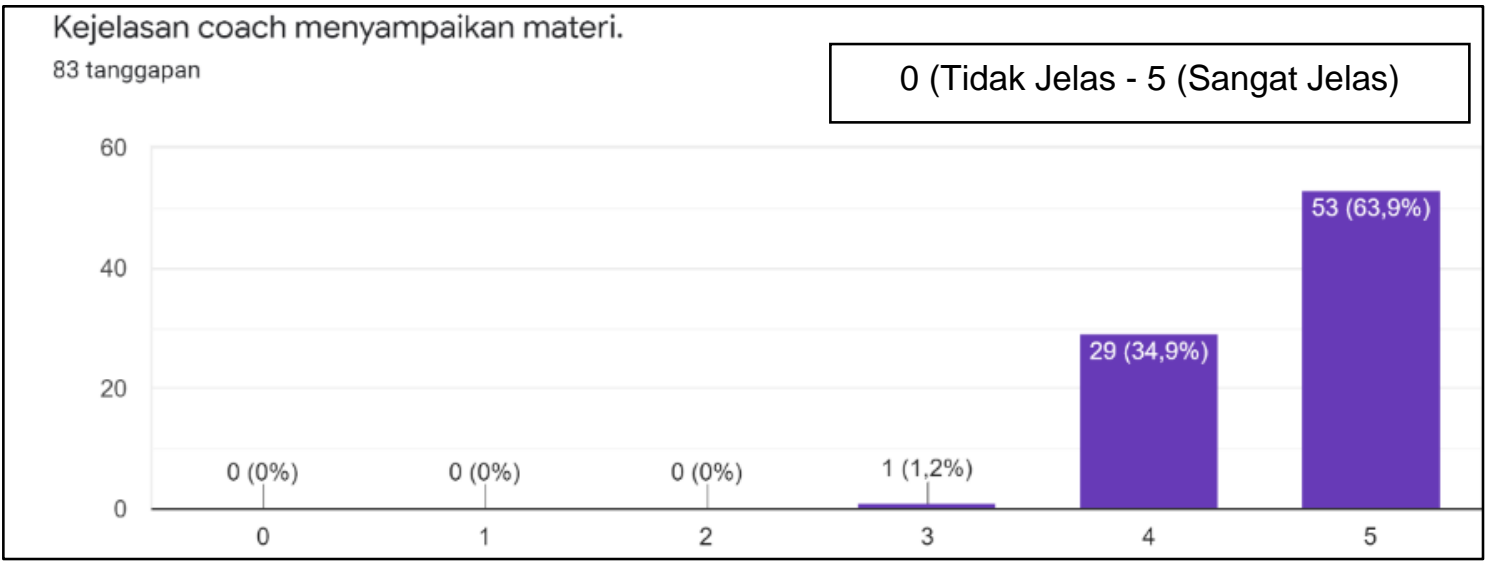

Gambar 10. Grafik tanggapan peserta mengenai kejelasan narasumber menyampaikan materi pelatihan.

Gambar 7 dan Gambar 8 juga menunjukkan pergeseran yang sama seperti pada Gambar 5 dan Gambar 6. Dari kedua grafik ini, bahkan ada peserta yang belum memiliki dasar apapun tentang media promosi, menjadi paham dan mampu membuat media promosi.

Selanjutnya Gambar 9 menunjukkan bahwa seluruh peserta pelatihan sepakat bahwa materi yang disampaikan memiliki nilai urgensitas yang tinggi. Dari sini, materi pelatihan mengenai desain promosi terintegrasi QR-Code yang dianggap mudah, namun pada praktiknya tetap banyak yang membutuhkan pendampingan. Terakhir,

Gambar 10 menunjukkan tanggapan peserta terhadap kejelasan narasumber dalam menyampaikan materi. Secara garis besar, peserta menganggap narasumber telah dapat menyampaikan materi dengan jelas.

\section{PENUTUP}

Dari rangkaian pelatihan dapat disimpulkan bahwa pelatihan yang bersifat daring, dalam praktiknya dilakukan secara kombinasi antara synchronouse dan asynchronouse dapat meningkatkan pengetahuan dan keterampilan peserta dalam membuat desain promosi visual yang terintegrasi dengan teknologi QR Code. Selanjutnya beberapa saran masukkan dari peserta pelatihan terkait dengan waktu pelatihan yang dinilai masih kurang. Antusiasme peserta pelatihan juga ditunjukkan dengan harapan diadakannya pelatihan serupa untuk media promosi jenis lainnya.

\section{DAFTAR PUSTAKA}

APJII, Survei Internet APJII 2016, https://apjii.or.id/content/read/39 /264/Survei-Internet-APJII2016.

Asare, I. T.; Asare, D., The effective use of quick response $(\mathrm{QR})$ code as a marketing tool, International Journal of Education and Social Science, 2015, Vol. 2, No. 12,6773. 
Basry, A.; Sari, E. M., Penggunaan Teknologi Informasi Dan Komunikasi (TIK) Pada Usaha Mikro, Kecil Dan Menengah (UMKM), Jurnal Komputer Dan Informatika, 2018, Vol. 2, No. 3, 53-60.

Čović, Z.; Šimon, J., Usage of QR codes in promotion on social networks, International Conference on Smart Systems and Technologies (SST), 2016, 123-127.

Daulay, S. S., Hubungan antara QR Code dan Dunia Industri dan Perdagangan, 2015.

Febriyantoro, M. T.; Arisandi, D., Pemanfaatan digital marketing bagi usaha mikro, kecil dan menengah pada era masyarakat ekonomi ASEAN, Jurnal Riset Manajemen dan Bisnis Dewantara (JMD), 2018, Vol.1, No.2, 61-76.

Haiqal, M. K.; Hidayat, S., Penerapan Identitas Visual pada Media Promosi Website Wisata Kerajinan $\quad$ Rajapolah, Desain Komunikasi Visual, Manajemen Desain dan Periklanan (Demandia), 2017,182-199.

Hayaty, M.; Meylasari, D., Implementasi Website Berbasis Search Engine Optimization (SEO) Sebagai Media Promosi, Jurnal Informatika, 2018, Vol. 5, No. 2, 295-300.

Hernandhi, D. T.; Astuti, E. S.; Priambada, S., Desain Sistem Informasi Pemasaran Berbasis
Website Untuk Promosi (Studi Kasus Pada Kedai Ayam Geprak \& Sambal Bawang Malang), Jurnal Administrasi Bisnis, 2018, Vol. 55, No. 1, 1-10.

Hidayat, W.; Mahmuriyah, R.; Safitri, S. N. R., Media Visual Berbentuk Katalog Produk Sebagai Media Promosi, Journal Sensi, 2016, Vol. 2, No. 2, 184-197.

Hossain, M. S.; Zhou, X.; Rahman, M. F., Examining the impact of $Q R$ codes on purchase intention and customer satisfaction on the basis of perceived flow, International Journal of Engineering Business Management, 2018, 10.

Irawan, J. D.; Adriantantri, E., Pemanfaatan QR-Code Segabai Media Promosi Toko, Jurnal Mnemonic, 2018, Vol. 1, No. 2.

Khair, H., Dampak atribut toko terhadap keputusan pembelian pada indomaret dept store di medan, Jurnal Ilmiah Manajemen dan Bisnis Mercu Buana, 2016, Vol. 2, No. 1, 96862.

Lin, L.; Wu, S.; Liu, S.; Jiang, B., Interactive $\quad \mathrm{QR}$ code beautification with full background image embedding, Second international workshop on pattern recognition, 2017, Vol. 10443, 1044317.

Mas' ud, M., Pemanfaatan Teknologi Sistem Informasi untuk Meningkatkan Penjualan Hasil Produk UMKM Logam di Kota 
Pasuruan, Engagement: Jurnal Pengabdian Kepada Masyarakat, 2017, Vol. 1, No. 2, 185-197.

Rewah, J., Pengaruh Promosi Berbasis Teknologi Informasi Terhadap Pengusaha Muda Universitas Klabat, Cogito Smart Journal, 2018, Vol. 4, No. 1, 24-36.

Triani, A. R.; Adriyanto, A. R.; Faedhurrahman, D., Media Promosi Bisnis Potensi Wisata Daerah Bandung Dengan Aplikasi Virtual Reality, Jurnal Bahasa Rupa, 2018, Vol. 1, No. 2, 136-146.
Yusantiar, R.; Soewardikoen, D. W., Perancangan Identitas Visual untuk Promosi Pariwisata Kabupaten Rembang, ANDHARUPA: Jurnal Desain Komunikasi Visual \& Multimedia, 2018, Vol. 4, Vol. 2, 207-220.

\section{UCAPAN TERIMAKASIH}

Penulis mengucapkan terimakasih kepada BLU Universitas Negeri Jakarta sebagai sumber pendanaan kegiatan pelatihan sesuai Surat Keputusan Rektor Universitas Negeri Jakarta Nomor: 476/UN39/KU.00.01/2020 Tanggal 11 Mei 2020. 